\title{
The Effect of Entrepreneurial Human Capital and Entrepreneurial Failure Learning on the Entrepreneurial Restart Intention
}

\author{
Le Quan $^{1} \&$ Hungta Huy ${ }^{2}$ \\ ${ }^{1}$ Vietnam National University, Hanoi, Vietnam \\ ${ }^{2}$ Vietnam University of Commerce, Hanoi, Vietnam \\ Correspondence: Le Quan, Vietnam National University, Hanoi, Vietnam. E-mail: lequan@vnu.edu.vn
}

Received: May 8, 2014 Accepted: June 26, 2014 Online Published: July 24, 2014

doi:10.5539/ass.v10n16p99

URL: http://dx.doi.org/10.5539/ass.v10n16p99

\begin{abstract}
Being an entrepreneur or continuing to work as a regular employee is a difficult decision a number of people are dealing with when choosing their career. The entrepreneurs can contribute for the economics' growth. However, because of the high rate of failure businesses, the failed entrepreneurs have to deal with amorous difficulties. This study has conducted to identify the life of the entrepreneurs who had failure experiences from the time after their failure to the recovery time of them. The quantitative method was conducted to find the relationship between the entrepreneurial human capital and the learning process from failure, the restart intention. The finding of this research indicated positive impact of entrepreneurial human capital and failure learning on restart intention. The research also provided evidences to scholars who are developing literature review of entrepreneurship to help them with a new researching direction about entrepreneurs' intentions and behaviors by using Motivation-Opportunity-Ability perspectives. Based on this study, failed entrepreneurs would be provided with different points of view about their collapse, as well as found some helpful mechanisms to use as resources and drew useful lessons from their failure to build up optimism in their future entrepreneurial career.
\end{abstract}

Keywords: entrepreneurship failure, entrepreneurial learning, entrepreneurship restart intention, entrepreneurial intention, human capital

\section{Introduction}

\subsection{Research Introduction}

Being an entrepreneur or continuing to work as a regular employee is a difficult decision a number of people are dealing with when choosing their career. Becoming an entrepreneur, who establishes, organizes, controls, and takes responsibility for a new business, can offers a person more chances to solve some difficulties so that many people may desire to be entrepreneur rather than a mere employee (Segal, Borgia, \& Schoenfeld, 2005). An individual chooses to be an entrepreneur for a wide range of reason. According to Gilad and Levine (1986), there are two kinds of closely related reasons of entrepreneurial motivation, the "push" theory and the "pull" theory. Negative external factors can be seen as the reason behind people who are pushed into becoming entrepreneurs, for example job loss, job issues, discomfort in traditional working environment, inflexible schedules and even insufficient incomes. On the other hand, the "pull" theory referred to the individual's internal factors including desire for independence, self-fulfillment, power, reputation and more which are the main factors impacting the decide to be an entrepreneur. Moreover, being entrepreneurs, people expect to be rewarded with the wages of employment (Van Praag \& Cramer, 2001) and also hope for brighter future in their life. Keeble, Bryson, and Wood (1992), Orhan and Scott (2001) and Segal et al. (2005) argued that the "pull" factors have more influences in entrepreneurial decision-making than the "push" factors.

However, deciding to become entrepreneurs, people have to deal with countless difficulties, challenges, and confrontations ahead. The threat can be derived from external environment as well as internal one. The critical role of entrepreneurship research which can be seen as the effect of entrepreneurial activities in establishing new business has been a key influence on the economy growth, employee and innovation (Guerrero, Rialp, \& Urbano, 2008). However, in the research conducted by Knott and Posen (2005), the author indicated that around 80-90 percent of new firm ultimately failed, a shocking figure. Approximately 10-20 percent of the surviving firms let the entrepreneurs achieve their business establishing goals such as high incomes, elevated reputations, and 
realistic ambition. Furthermore, the data from the U.S. Census Business Information Tracking Series in the study conducted by Headd (2003) mentioned that the failure was not the same in the new firms. The number of firm death in the first four years reached 51 percent. The same rate on the young failure firms with the smaller than five years olds which was 40 to 60 percent on the U.S. firms filed for bankruptcy from 1950 to 1987 (White, 1989) while adopted to the Warren and Westbrook (1999) study, they reported that 80 percent of the firms in the United States which filled the bankruptcy law had the assets lower than $\$ 1$ million, and 88 percent reported that they had fewer than 20 employees. That is the case in the United States, the cases in the other countries such as in Japan, the annual average number of firm bankruptcies during the 1990s was 14.500 (Peng \& Barney, 2007), in France 52,000, in Great Britain was 47,000, and in Germany was 21,000 during 1990s (Claessens, Djankov, \& Klapper, 2003; Peng \& Barney, 2007). While the failure business is very high, in the literature, entrepreneurship and their action which have attracted lots of researchers (Hannafey, 2003) with their concentration on finding the factors which bring on the success in the entrepreneurial ventures. But the consideration lay on the lives of the majority who failed-their families, social network, and psychology as well as physiology. The question this research aimed to answer is how they can use their entrepreneurial resource (human capital) and their learning ability to overcome their grief and intend to restart.

\subsection{Research Gaps}

Entrepreneurship played an important role in the creation of new economic entities, which is central to the evolution of organization and economies (Kim, Aldrich, \& Keister, 2003). And in order to contribute to the national economic growth and development, entrepreneurial activity has an critical task to encourage innovation, job creation and also global and national competitiveness (Bednarzik, 2000; Keister, 2000; Kim et al., 2003). But to execute such tasks, entrepreneurs need to have strong and massive resources to support them. For example: based on financial capital perspective, if former wealth or high current income is necessary for starting business, people who are already financially advantaged will be most likely to attempt to be entrepreneurs; or having sufficient human capital also encourages people to become entrepreneurs (Kim, Aldrich, \& Keister, 2006). But in fact, most of entrepreneurs cope with lack of resource including human capital and the social capital, etc. The business failures are partly derived from these reasons. Various previous researches indicated supporting relationship between the entrepreneurial capital (human capital, social capital) and the pursuit of starting-up business (Kim et al., 2003, 2006). However, those researches did not mention the role of entrepreneurial human capital in the period after firm failure. The question is that if the failure entrepreneurs had these rich resources, have they intended the intention to restart business. Or they considered about the resources which they used for the first failure business was huge, and they did not think that they will have the restart business intention. Therefore, in this research, we will examine the impacted role of entrepreneurial human capital in association with entrepreneurial restart intention.

\section{Literature Review}

\subsection{Motivation-opportunity-ability Frameworks}

The predecessor of the Motivation-Opportunity-Ability (MOA) framework was accepted in theory by the industrial psychologists and research by social psychologists (Siemsen, Roth, \& Balasubramanian, 2008). In the initial period, MOA framework only consisted of Motivation and Ability, and the factor Opportunity was later added in the framework (Blumberg \& Pringle, 1982; Peters \& O'Connor, 1980; Siemsen et al., 2008). According to some authors (Bendoly \& Hur, 2007; Mathieu, Tannenbaum, \& Salas, 1992), there are connections between the three factors: Motivation, Opportunity and Ability. However, the exact relationship between those factors in the MOA framework is difficult to justify theoretically (Siemsen et al., 2008).

In MOA framework, Motivation attracts the most controversial debates and discussions from scholars in literature review (Siemsen et al., 2008). Motivation theory was used to predict individual behavior. Researchers Ambrose and Kulik (1999) indicated that the definition, measuring and mediating impact of motivation were the biggest difficulties. In this research, we used the definition from Hughes that: "Motivation is the impetus toward a behavior or the motivation captures the individual's willingness to act" (Hughes, 2007). Another definition was created by Bayton (1958) stating that motivation is "the drives, wishes, urges or desires which initiate the sequence of events knows as behavior" (Bayton, 1958). In this research, we use the Motivation factor clarify the entrepreneur's leads to their behavior. Moreover, from the basic concepts of psychology: Ability is the skills and capabilities requisite to the performance of a behavior and Opportunity mentions the contextual and situational constraints relevant to the performance of the Behavior (Rothschild, 1999).

Moreover, our study provides conceptual ways of MOA framework usage in researching. MOA framework was applied in various management researches. It was well employed as a theoretical basic for explanation of work 
performance (Blumberg \& Pringle, 1982; Boudreau, Hopp, McClain, \& Thomas, 2003). MOA framework also has been used to clarify a wide range of behaviors. For example, the framework could explain consumer choice (MacInnis, Moorman, \& Jaworski, 1991), firm-level decision making (Wu, Balasubramanian, \& Mahajan, 2004), and social capital activation (Adler \& Kwon, 2002; Binney, Hall, \& Oppenheim, 2006). In recent times, knowledge-management practices has also been using MOA framework as a conceptual organizing (Argote, McEvily, \& Reagans, 2003), and knowledge-sharing tool (Siemsen et al., 2008). MOA framework was not only used in management researches, but also implemented in the field of entrepreneurship (Davidsson, 1991; Stevenson \& Jarillo, 1990). The basic level of MOA framework in entrepreneurship research occurs at the intersection of the ability of the entrepreneurs (including their human capital and social capital), their motivation as well as their opportunities from external environment.

In entrepreneurship research, scholars focused on individual-level factor matters with the knowledge of entrepreneurs taking over center stage. According to the research conducted by (Venkataraman, 2002), knowledge can contribute the opportunity recognition, and former knowledge also influences opportunity exploration. While prior knowledge of entrepreneurs included a number of components, Rosenbusch, Brinckmann, and Bausch (2011) found that education, start-up experience, management and work experience were used in order to measure human capital. According to Shane (2000), knowledge plays a fundamental role in human capital in foundation, while human capital leads to discovery of entrepreneurial opportunities. Consequently when human capital of entrepreneurs referred to the Entrepreneur's Ability, it has positive relationship with Opportunity of entrepreneurs. Accordingly, in this study, learning from the previous business failure can be seen as rich source for failed entrepreneur (McGrath, 1999). It is also a great inspiration for failed entrepreneurs to comprehend their experience and useful past lessons in preparing for their future. But what kind of lessons they should learn from prior failure, and how can they learn? It depends on the entrepreneurs' ability, whether they have enough knowledge to realize learning worthy lessons and use useful networking to learn more effectively. Based on this argument, ability which represents Entrepreneurial Resource will be useful for learning motivation.

\subsection{Definition}

Entrepreneurial Human Capital: Entrepreneur-specific human capital includes a person's previous experience and family background in entrepreneurship. Human capital can be defined as an investment in skill and knowledge that boosts earning power and it was the main factor in new business formation. Moreover, education, workplace experience, and family ties are the most common indicators of human capital used in labor analyses (Bates, 1997; Greene, 2000). When the research mentioned about education, there are two dimensions can be viewed in the decision to become an entrepreneur related to the acquisition of skill and credentialing. The role of skill including general business and industry specific skills might help entrepreneurs avoid some basic mistakes and also assist them in setting up basis business functions while formal education (credentials) contributes an access into social networking (such as: alumni network) or serves as an indicator in evaluation of resources (such as: venture capital financing).

Entrepreneurial Failure Learning: There are varieties of lessons that failed entrepreneurs can learn from previous experience's failure such as self-discovery and learning about networks/relationships (Cope, 2011). Identity lesson learned referred to the learning about strengths, weaknesses, skills, attitudes, beliefs, and areas for development (Mezirow, 1991). The combination between transformative and double-loop learning provides the fundamental learning about networks and relationships of failure entrepreneurship. Learning about networks and relationships introduced the nature of relationship management, both internal and external to the venture (Cope, 2005, 2011; Gibb, 1997).

In this research, the author focuses on two distinct learning outcomes of failure which originated from double-loop and single-loop learning, respectively. While single-loop learning concerned about the basis for modifying what is already known, double-loop learning referred to the foundation for adjusting overall norms and beliefs (Argyris, 1976). The double-loop learning is also mentioned in the research by Cope (2011) as a fundamental concept for entrepreneurial failure learning of networks and relationships.

Entrepreneurial Restart Intention: In this research, we pay attention to the Shapero and Sokol (1982) model of "entrepreneurial event" (SEE). Adapting to SEE model, an individual choice to establish a new business based on a number of components: perceived feasibility, perceived desirability and propensity to act (Krueger Jr, Reilly, $\&$ Carsrud, 2000). They defined in their research that perceived desirability is likely the degree to which people want to find chance of establishing a new venture attractive and fundamentally, which has the effect on entrepreneurship. On the other hand, perceived desirability in Krueger's research referred to individual 
attractiveness of setting up new business which closely related to attitude and subjective norm variables (Shepherd, 2003). Perceived feasibility is the degree to which people believe that they can have enough capability to start a new business. According to Chen, Greene, and Crick (1998), people with higher feasibility have more intrinsic interest in duties and more persistent if facing difficulties.

\subsection{Research Framework and Hypothesis Development}

Base on the research's motivation and objective, the author built a conceptual framework for this research.

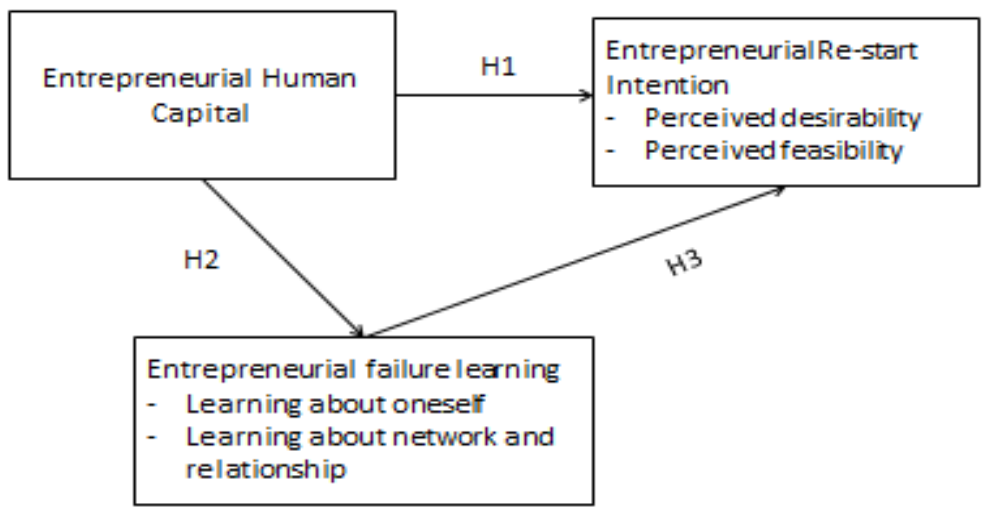

Figure 1. Research framework and hypothesis development

\subsubsection{The Effect of Entrepreneurial Human Capital on Restart Intention}

The influence of entrepreneurial resource on entrepreneurial restart intention can be viewed by considering the impact of the human capital on entrepreneurial intention. The impact of education on decision becoming entrepreneurs signified that the higher the education people received the more likely they became entrepreneurs (entrepreneurial intentions) (Bates, 1997; Fairlie \& Meyer, 1996). Moreover, education also has a positive association on self-employment not only for male but also for female entrepreneurs (Carr, 1996; Robinson \& Sexton, 1994). On the other hand, entrepreneurship experience, another variety of human capital, was proved to be related to blossoming entrepreneurs (Kim et al., 2003). According to several previous researches (Kim et al., 2006; Klepper, 2002; Lazear, 2004; Phillips, 2002), human capital has been considered as the critical factors in influencing a start-up decision. However, a research conducted by (Kim et al., 2003) argued that the acquisition of skills and credentials which are the important measurement of human capital may create more attractive opportunities for an individual to work for others, rather than to pursue own business. In addition, the data from General Social Survey in 1991 pointed that education was negatively related to self-employment (Butler \& Herring, 1991).

Hypothesis 1: Entrepreneurial Human Capital positively impacts on the Entrepreneurial Restart Intention.

\subsubsection{The Effect of Entrepreneurial Human Capital on Entrepreneurial Learning}

How can entrepreneurial human capital impact on the learning process of failed entrepreneurs? A research conducted by Politis (2005) found that various learning experiences can be exposed to failed entrepreneurs as knowledge. Moreover, new knowledge can be gained when entrepreneurs have a comprehensive grasp of business failure experience and transform those experiences into knowledge (Politis). There are four distinct learning abilities: experiencing, reflecting, thinking and acting. Based on those steps, entrepreneurial human capital can be utilized. Entrepreneurs, who had the more human capital, useful education and rich experiences, have more ability to transfer business failure experience into their knowledge in the future by highly reflecting prior failure and putting elevated thought into the causes of failure. Based on the valuable lessons learned, the failure entrepreneurs can impact an entrepreneur's motivation and decision to continue his/her entrepreneurship career or to start a venture (Cardon, Stevens, \& Potter, 2011).

Hypothesis 2: Entrepreneurial Human Capital positively impacts on Entrepreneurial Learning

\subsubsection{The Effect of Entrepreneurial Failure Learning on Entrepreneurial Restart Intention}

Cope (2005) mentioned that learning from experience is the main kind of entrepreneurial learning, and that it is necessary to understand more deeply how entrepreneurs learn formative experiences, which related to the entrepreneurial learning "mechanisms". In order to comprehend the learning mechanism, (Cope, 2005; Rae \& 
Carswell, 2000) suggest that significant "events" or "episodes" have an important role in motivating entrepreneurial learning. A numbers of previous researches have pointed the changing outcomes of experiential learning in entrepreneurship. For example, some authors mentioned the changes in thinking and behaviour of entrepreneurs, improvement in entrepreneurial knowledge, and adjustment of firm strategy and practices (Cope, 2003; Cope \& Watts, 2000; Deakins \& Freel, 1998). Such entrepreneurs learned from the failure of business which can be used as the useful lessons in their recovery and their intention to restart new business.

Moreover, Minniti and Bygrave (2001) asserted that "entrepreneurs learn by updating a subjective stock of knowledge accumulated on the basis of past experiences" (p.5). Based on MOA concept as mention above, in the failure of entrepreneurs, the awareness of useful and necessary lessons from the firm's failure included lessons related to learning about themselves: strengths and weaknesses, opportunities and threats, or requirements for growth. Learning about network and management (Cope, 2005) is extremely necessary for once-failed entrepreneurs to gain more knowledge and improve their experience. Based on traditional experiential learning model, the final phase of the cycle is actively testing new knowledge (Argyris, 1976; Ellis, Mendel, \& Nir, 2006) Nevertheless, new knowledge which entrepreneurs had learned from their failure can be tested when they are motivated to restart their business. Based on this argument, we build hypothesis 3 as following.

Hypothesis 3: Entrepreneurial Failure Learning positively impacts on Entrepreneurial Restart Intention.

\section{Methodology}

\subsection{Research Methodology}

This research is conducted by using Quantitative method. A hypothesis would be stated and the researchers attempted to accept or reject that hypothesis. These techniques are usually easy to measure as the generated data can be analyzed mathematically.

\subsubsection{Confirmatory Factor Analysis (CFA) and Reliability Test}

In this study, Amos 18.0 was employed to perform the confirmatory factor analysis (CFA). CFA was applied in order to confirm the structural validity and examine the correlation coefficients of each variable and factor to verify its legitimacy before the reliability test.

The reliability test measures consistency or stability of the examinee's performance in the test. It is often measured with Cronbach's alpha $(\alpha)$. A test with high reliability means that examinee's performance will show similar results in different occasions. Although a reliability test defines one of the most significant elements of test quality, high consistency is still not a sufficient condition for validity (Pedhazur \& Schmelkin, 1991). Validity refers to how well a test accomplishes our intended measuring subjects. A highly valid test possesses items that accurately linked with the testing purpose.

\subsubsection{Structural Equation Modeling}

The Structural Equation Model (SEM) includes an entire family of models known as covariance structure analysis, latent variable analysis, confirmatory factor analysis and often simply LISREL analysis. SEM combines the logic of CFA, multiple regressions and path analysis in an application using a single technique (Henley, Shook, \& Peterson, 2006). The aim of using the SEM is to determine how well the hypothesized model fits in the observed data. More specifically, this technique determines whether the hypothesized causal structure is consistent with the correlation of covariance matrix of the data being considered (Henley et al., 2006). This method was wide used in social research such as in human resource management research(Lin \& Shih, 2008), operation management research (Shah \& Goldstein, 2006). So in order to find out the relationship of the whole research model in this study, SEM will be used. We also used Amos software to analyze and specify the relationship among the entire researching framework and variables in this model.

To access overall model fit, we use the chi-square test and additional the fit indices: Chi-Square (p-value); Degree of freedom; GFI; AGFI; RMSEA (Hu \& Bentler, 1998).

\subsection{Data Collection}

The primary data was collected by questionnaires of entrepreneurs with past failure experiences in Viet Nam, including those from Hanoi, Da Nang, and Ho Chi Minh city. Moreover, the authors also conducted direct interviews with entrepreneurs who suffered from business failure to gather their ideas about this issue of the research. The questionnaire was established based on previous research and questions were modified in order to fit with the objective of this research -In this research, in order to find the effect of Entrepreneurial Human Capital and Learning on the Entrepreneurial Restart Intention, the authors built a conceptual framework and used quantitative method to indicate the relationship between the Entrepreneurial Human Capital, Failure Learning 
and Restart Intention.

There are three main groups in the questionnaire. Firstly, the construction of Human capital consists of 5 items, which were taken from studies ofSubramaniam and Youndt (2005) and Youndt, Subramaniam, and Snell (2004). Participants responded on a seven-point Likert rating scale ranging from 1 (strongly disagree) to 7 (strongly agree). The items were adapted to describe services related to knowledge, skills, and abilities. Secondly, to estimate the failed entrepreneurs' perception about Entrepreneurial Learning, 7 items from Shepherd, Patzelt, and Wolfe (2011) study was appropriately adopted to this research. Thirdly, Entrepreneurial Restart Intention can be perceived as the re-intention of an individual to set up a new venture sometimes in the future. In this study, the questionnaire were adapted and developed by researchers Douglas and Shepherd (2002), Krueger (1993), and Segal et al. (2005). In this research, those items have been measured by using the seven-point Liker-scale from 1 (strong disagree) to 7 (strong agree).The complete questionnaire is presented in the Appendix.

Table 1. Characteristics of research respondent $(\mathrm{N}=216)$

\begin{tabular}{llll}
\hline Question & Categories & Frequency & Percentage \\
\hline Gender & Male & 129 & 60 \\
Age & Female & 87 & 40 \\
& $0-20$ years old & 0 & 0 \\
& 21-30 years old & 150 & 69.4 \\
& $31-45$ years old & 55 & 25.46 \\
& $46-60$ years old & 12 & 5.54 \\
Education & More than 60 years old & 0 & 0 \\
& PhD & 2 & 0.86 \\
& Master & 35 & 16.2 \\
& Bachelor & 170 & 78.8 \\
& High School & 7 & 3.2 \\
& Primary School & 1 & 0.4 \\
Number of household & Other & 2 & 0.8 \\
& $1-3$ people & 88 & 40.74 \\
& 4-5 people & 102 & 47.22 \\
& More than 5 people & 26 & 12.04
\end{tabular}

\section{Research Result}

\subsection{Factor Analysis and Reliability Tests}

\subsubsection{Entrepreneurial Human Capital}

As show in Table 2, Entrepreneurial Resource is constructed in order to reach the criteria of the $x^{2} / D$.F $<3$, GIF $>$ 0.8 , AGFI $>0.8$, CFI $>0.9$, RMSEA $<0.08$. Although RMSEA is little bigger than the rule of thumbs, all of the criteria was satisfied as Chi-Square/d.f $=2.921, \mathrm{GFI}=0.984$, AGFI $=0.918$, and the factor loading of all items are over than 0.3 . Thus, all of items are keeping for the next step in this research.

Table 2. Confirmatory factor analysis result for entrepreneurial human capital

\begin{tabular}{llll}
\hline Construct & Variable & Factor Loading & C.R (t-value) \\
\hline & Ehc1: I am highly skilled & $0.828^{* * *}$ & 12.984 \\
Entrepreneurial & Ehc2: I am widely considered the best in our industry & $0.816^{* * *}$ & 12.851 \\
Human Capital & Ehc3: I am creative and bright & 0.849 & $\mathrm{~A}$ \\
& Ehc4: I am experts in their particular jobs and functions & $0.398^{* * *}$ & 5.487 \\
& Ehc5: I develop new ideas and knowledge & $0.523^{* * *}$ & 7.100 \\
\hline
\end{tabular}

Note: Ehc: Entrepreneurial human capital;

Fit Index: Chi-Square (p-value) $=8.762$; Degree of freedom $($ d.f $)=3$; Chi-Square/d.f $=2.921$; GFI $=0.984$; $\mathrm{AGFI}=0.918 ;$ RMSEA $=0.095$. 


\subsubsection{Entrepreneurial Failure Learning}

As indicated in Table 3, all factor loadings of the 7 items in Entrepreneurial Failure Learning exceed the threshold of 0.4. Those items also satisfied the criteria including $\mathrm{x}^{2} / \mathrm{D} . \mathrm{F}<3$, GIF $>0.8$, AGFI $>0.8, \mathrm{CFI}>0.9$, RMSEA $<0.08$. Subsequently, we keep all 7 items in this construct in order to conduct the next step of this research.

Table 3. Confirmatory factor analysis result for entrepreneurial failure learning

\begin{tabular}{llll}
\hline Construct & Variable & Factor Loading & C.R (t-value) \\
\hline & Eol1: After failure, I can understand deeply about my strong point & $0.705^{* * *}$ & 13.791 \\
& Eol2: I also can understand more about my weakness point & 0.798 & $\mathrm{~A}$ \\
& Eol3: I can aware which is really important in my life and my family & $0.842^{* * *}$ & 11.941 \\
Entrepreneurial & Eol4: I can set a clear goal in the future & $0.658^{* * *}$ & 9.488 \\
Learning & $\begin{array}{l}\text { Enl1: I have learned a useful lesson about the customer's need as } \\
\text { well as the market }\end{array}$ & 0.862 & $\mathrm{~A}$ \\
& $\begin{array}{l}\text { Enl2: I can build a strong relationship with my partners after learning } \\
\text { the lesson from failure }\end{array}$ & $0.618^{* * *}$ & 8.020 \\
& Enl3: I am more willing to help others deal with their failure & 0.363 & 4.831
\end{tabular}

Note: Eol: Learning about oneself; Enl: Learning about network and relationship;

Fit Index: Chi-Square $(p$-value $)=24.634$; Degree of freedom $($ d.f $)=12$; Chi-Square/d.f $=2.053$; GFI = 0.967; AGFI $=0.924 ;$ RMSEA $=0.070$.

\subsubsection{Entrepreneurial Restart Intention}

Table 4 shows that 5 out of 7 items of Entrepreneurial Restart Intention including Erid1, Erid3, Erid4, Erif1 and Erif2, have high loading scores which pass the requirement of 0.4. Based on the research of (Dillon \& Goldstein, 1984), item which have the factor loading over 0.3 but not lower than 0.3 should be kept. In this construct, three items including Erid2, Erif3 were deleted due to either lowering factor loading or getting the rule of thumb. After deleting those items, the result from table 4-7 shows good model fit (including $\mathrm{x}^{2} / \mathrm{D} . \mathrm{F}<3, \mathrm{GIF}>0.8, \mathrm{AGFI}>0.8$, CFI $>0.9$, RMSEA $<0.08)$. All of the rules of thumbs are satisfied.

Table 4. Confirmatory factor analysis result for entrepreneurial re-star intention

\begin{tabular}{llll}
\hline Construct & Variable & Factor Loading & C.R(t-value) \\
\hline & Erid1: I would love to be an entrepreneur & $0.615^{* * *}$ & 7.786 \\
& $\begin{array}{l}\text { Erid2: To be an entrepreneur is my honor } \\
\text { Erid3: I am considering re-starting my own business some } \\
\text { day in the future }\end{array}$ & Delete & A \\
Entrepreneurial & Erid4: To be an entrepreneur is very hard & 0.942 & 2.381 \\
Restart Intention & $\begin{array}{l}\text { Erif1: I am certain in this restart firm } \\
\text { Erif2: I am sure about myself to re-stat business }\end{array}$ & 0.688 & 8.786 \\
& $\begin{array}{l}\text { Erif3: I can recovery my losing reputation when I restart } \\
\text { my own business }\end{array}$ & $0.923^{* * *}$ & Delete \\
\hline
\end{tabular}

Note: Erid: Entrepreneurial Perceived Desirability; Erif: Entrepreneurial Perceived Feasibility;

Fit Index: Chi-Square $(p-v a l u e)=4.134$; Degree of freedom $($ d.f $)=4$; Chi-Square/d.f $=1.033$; GFI = 0.992; AGFI $=0.971 ;$ RMSEA $=0.012$.

\subsection{The Result of Structure Equation Model}

In order to answer the research question, a conceptual framework was build. After running data with AMOS software by Structure Equation Model method, table 5 showed result of this research. 
Table 5. The result of structure equation model

\begin{tabular}{llll}
\hline Relations & & Standardized Coefficients & C.R. \\
\hline & Hc1 & 0.677 & A \\
Entrepreneurial Human Capital(EHC) & Hc2 & $0.806^{* * *}$ & 9.036 \\
& Hc3 & $0.692^{* * *}$ & 8.328 \\
& Hc4 & $0.164^{* *}$ & 2.142 \\
Entrepreneurial Learning (EL) & Hc5 & $0.562^{* * *}$ & 7.015 \\
& EOL & $0.81^{* * *}$ & 6.567 \\
Entrepreneurial Restart Intention(ERI) & ENL & 0.825 & $\mathrm{~A}$ \\
EHC $\rightarrow$ ERI & ERID & $0.723^{* * *}$ & 5.882 \\
EHC $\rightarrow$ EL & ERIF & 0.911 & $\mathrm{~A}$ \\
EL $\rightarrow$ ERI & & $0.185^{*}$ & 1.722 \\
N & & $0.583^{* * *}$ & 6.136 \\
& & $0.332^{* *}$ & 2.836
\end{tabular}

Note: Hc: human capital; EOL: Learning about oneself; ENL: Learning about network and relationship; ERID: Erid: Entrepreneurial Perceived Desirability; ERIF: Entrepreneurial Perceived Feasibility;

Standard errors are in parentheses: ${ }^{*} \mathrm{p}<0.1 ;{ }^{* *} \mathrm{p}<0.05 ;{ }^{* * *} \mathrm{p}<0.001$;

Fit Index: Chi-Square (p-value) $=31.184$; Degree of freedom $(\mathrm{d} . \mathrm{f})=23$; Chi-Square/d.f $=1.356$; GFI $=0.968$; AGFI $=0.937 ;$ RMSEA $=0.041$.

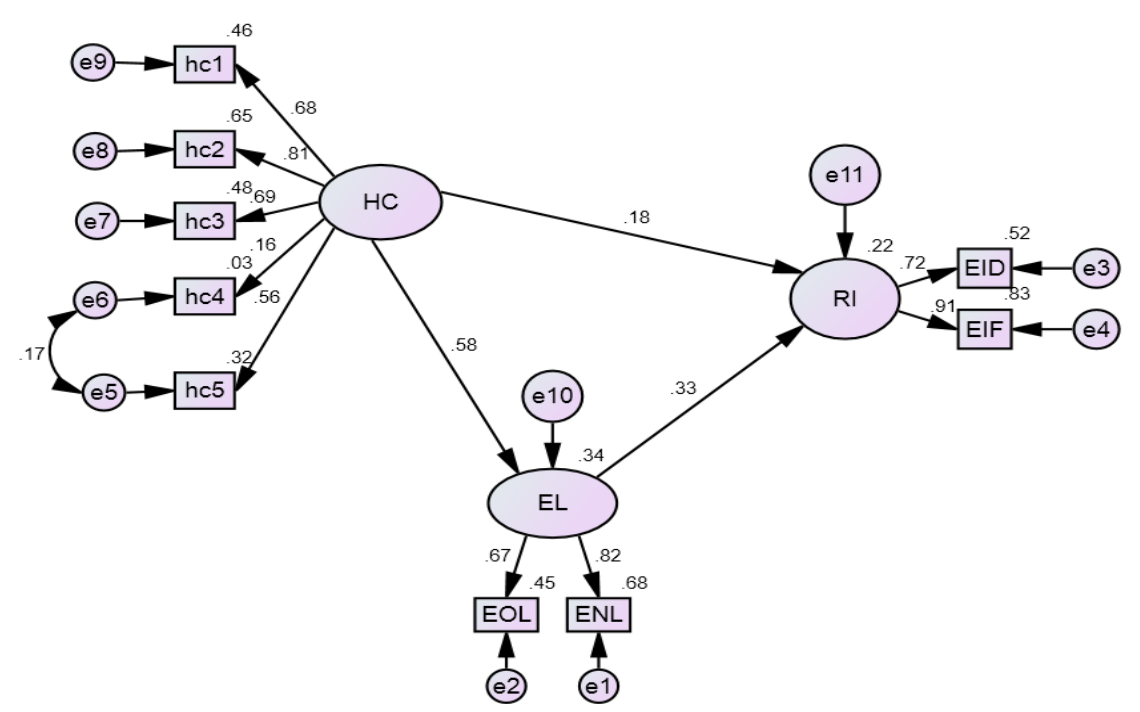

Figure 2. Research result

\section{Conclusion}

Entrepreneurial Human Capital has partially positive impact on the Entrepreneurial Restart Intention. Human capital theory mentioned that knowledge may enhance their cognitive abilities, leading to more productive and efficient potential activity (Becker, 2009; Davidsson \& Honig, 2003). As a result, if the profitable opportunities exist in economic system, people who have more human capital should be better at perceiving them. For entrepreneurship research, such entrepreneurs should also have superior ability in exploiting opportunities. But this theory has some limitations such as essentially taking a black box view of educational production and accumulative activities at equilibrium. That is the reason some researchers in entrepreneurship field made argument that total previous investment in human capital may influence career life choice, including entrepreneurial attitude towards entrepreneurial activities, by various ways (Davidsson \& Honig). Moreover, formal education can be seen as one pivotal component of human capital that can support the accumulation of explicit knowledge and can provide useful skill for entrepreneurs. Nonetheless, the result of previous research 
acknowledged that the relationship between education, entrepreneurship and success, with education frequently producing nonlinear effect on supporting the probability of becoming an entrepreneur or in achieving success (Bellu, Davidsson, \& Goldfarb, 1990; Gimeno, Folta, Cooper, \& Woo, 1997). Therefore, those result accredited that there is nonlinear between the people with high level of education as high human capital and entrepreneurial success or entrepreneurial activities. When formal education was treated as a component of human capital, human capital also includes experience of informal education. So for this factor, the previous research showed that labor market experience, management experience, and previous entrepreneurial experiences are important related to entrepreneurial activities (Bates, 1997; Gimeno et al.). Based on those results, although failed entrepreneurs can get more knowledge from their failure, they should consider impact of other factors to build their restart intention as well.

Entrepreneurial Learning has positive impact on the Entrepreneurial Restart Intention. Learning is often viewed as an essential outcome of entrepreneurial failure (Cope, 2003; Corbett, Neck, \& DeTienne, 2007; Shepherd, 2003). Business failures can be perceived as rich source of feedback for entrepreneurs about their effectiveness of decision-making (Corbett et al., 2007; Minniti \& Bygrave, 2001), as well as their management's skills, network and relationship. In this research, based on our result of over 200 failure entrepreneurs, we provide more evidences that learning process from their previous failure has positive affiliation with intention of to restart business in the future. The result of this research is accuracy when we compare with the result of previous researches which was presented in the research of (Minniti \& Bygrave, 2001),acknowledging that knowledge gained from failure can be applied in subsequent entrepreneurial endeavors so that they can get more success in the future. And the evidence abounds with highly successful entrepreneurs attributing their current success to learning from past failures. Thus, the more failure lessons entrepreneurs learned, the more intention they have to restart business in the future. Moreover, the mediating role of learning from prior business failure in relationship between entrepreneurial failure social/psychological costs and entrepreneurial restart intention was proved by the support of hypothesis 4 and hypothesis 5. Interestingly, this result shows entrepreneurial failure learning as a full mediator. Thus, without the full mediator of entrepreneurial failure learning, we cannot find the direct relationship of the failure costs and the intention to restart business of failed entrepreneurs. Based on those results, this research reaches the target to find the role of entrepreneurial failure learning for failed entrepreneurs to develop intention to restart business.

\section{Suggestion for Future Research}

Although this research attempts to conceptualize the relationship between the costs of failure entrepreneurs with their lessons learning and the re-start intention, the role of entrepreneurial human capital as well, its sample was only collected in Vietnam with the large portion of private and small and medium firms. Given to this condition, the result might vary in different geographic areas with different cultures. Thus, the suggestion for the future research is that: (1) other research should be extend to big firms with the huge of investment and the huge of management's operation; (2) research should conduct studies in different geography or context with the similar or contrast cultures for more accurate model.

In addition, in this study, authors mentioned that there is the time lag between the costs of entrepreneurs and the learning study process, the intention of those as well. So, in the future, the researchers should pay more attention on this issue in order to clarify the time line of those factors. It is necessary for the researcher to deeply get more knowledge about this issue. The audiences also can have more accuracy point of view in this situation. In consequence, the future research should try the longitudinal approach to compare the variation of the result in the different timeline.

\section{References}

Adler, P. S., \& Kwon, S. W. (2002). Social capital: Prospects for a new concept. Academy of Management Review, 27(1), 17-40.

Ambrose, M. L., \& Kulik, C. T. (1999). Old friends, new faces: Motivation research in the 1990s. Journal of Management, 25(3), 231-292. http://dx.doi.org/10.1177/014920639902500302

Argote, L., McEvily, B., \& Reagans, R. (2003). Managing knowledge in organizations: An integrative framework and review of emerging themes. Management Science, 49(4), 571-582. http://dx.doi.org/10. 1287/mnsc.49.4.571.14424

Argyris, C. (1976). Theories of action that inhibit individual learning. American Psychologist, 31(9), 638-654. http://dx.doi.org/10.1037/0003-066X.31.9.638

Bates, T. (1997). Race, self-employment, and upward mobility: An illusive American dream. Washington: The 
Woodrow Wilson Center Press.

Bayton, J. A. (1958). Motivation, cognition, learning: Basic factors in consumer behavior. The Journal of Marketing, 22(3), 282-289. http://dx.doi.org/10.2307/1247119

Becker, G. S. (2009). Human capital: A theoretical and empirical analysis, with special reference to education. Chicago: University of Chicago Press.

Bednarzik, R. W. (2000). The role of entrepreneurship in US and European job growth. Monthly Labor Review, 123(1), 3-16.

Bellu, R. R., Davidsson, P., \& Goldfarb, C. (1990). Toward a theory of entrepreneurial behaviour: Empirical evidence from Israel, Italy and Sweden. Entrepreneurship \& Regional Development, 2(2), 195-209. http://dx.doi.org/10.1080/08985629000000013

Bendoly, E., \& Hur, D. (2007). Bipolarity in reactions to operational 'constraints': OM bugs under an OB lens. Journal of Operations Management, 25(1), 1-13. http://dx.doi.org/10.1016/j.jom.2005.08.004

Binney, W., Hall, J., \& Oppenheim, P. (2006). The nature and influence of motivation within the MOA framework: Implications for social marketing. International Journal of Nonprofit and Voluntary Sector Marketing, 11(4), 289-301. http://dx.doi.org/10.1002/nvsm.280

Blumberg, M., \& Pringle, C. D. (1982). The missing opportunity in organizational research: Some implications for a theory of work performance. Academy of Management Review, 7(4), 560-569.

Boudreau, J., Hopp, W., McClain, J. O., \& Thomas, L. J. (2003). On the interface between operations and human resources management. Manufacturing \& Service Operations Management, 5(3), 179-202. http://dx.doi.org /10.1287/msom.5.3.179.16032

Butler, J. S., \& Herring, C. (1991). Ethnicity and entrepreneurship in America: Toward an explanation of racial and ethnic group variations in self-employment. Sociological Perspectives, 34(1), 79-94. http://dx.doi.org/ $10.2307 / 1389144$

Cardon, M. S., Stevens, C. E., \& Potter, D. R. (2011). Misfortunes or mistakes? Cultural sensemaking of entrepreneurial failure. Journal of Business Venturing, 26(1), 79-92. http://dx.doi.org/10.1016/j.jbusvent. 2009.06.004

Carr, D. (1996). Two paths to self-employment? Women's and men's self-employment in the United States, 1980. Work and Occupations, 23(1), 26-53. http://dx.doi.org/10.1177/0730888496023001003

Chen, C. C., Greene, P. G., \& Crick, A. (1998). Does entrepreneurial self-efficacy distinguish entrepreneurs from managers? Journal of Business Venturing, 13(4), 295-316. http://dx.doi.org/10.1016/S0883-9026(97) 00029-3

Claessens, S., Djankov, S., \& Klapper, L. (2003). Resolution of corporate distress in East Asia. Journal of Empirical Finance, 10(1), 199-216. http://dx.doi.org/10.1016/S0927-5398(02)00023-3

Cope, J. (2003). Entrepreneurial learning and critical reflection discontinuous events as triggers for 'higher-level' learning. Management Learning, 34(4), 429-450. http://dx.doi.org/10.1177/1350507603039067

Cope, J. (2005). Toward a dynamic learning perspective of entrepreneurship. Entrepreneurship Theory and Practice, 29(4), 373-397. http://dx.doi.org/10.1111/j.1540-6520.2005.00090.x

Cope, J. (2011). Entrepreneurial learning from failure: An interpretative phenomenological analysis. Journal of Business Venturing, 26(6), 604-623. http://dx.doi.org/10.1016/j.jbusvent.2010.06.002

Cope, J., \& Watts, G. (2000). Learning by doing-An exploration of experience, critical incidents and reflection in entrepreneurial learning. International Journal of Entrepreneurial Behaviour \& Research, 6(3), 104-124. http://dx.doi.org/10.1108/13552550010346208

Corbett, A. C., Neck, H. M., \& DeTienne, D. R. (2007). How corporate entrepreneurs learn from fledgling innovation initiatives: Cognition and the development of a termination script. Entrepreneurship Theory and Practice, 31(6), 829-852. http://dx.doi.org/10.1111/j.1540-6520.2007.00208.x

Davidsson, P. (1991). Continued entrepreneurship: Ability, need, and opportunity as determinants of small firm growth. Journal of Business Venturing, 6(6), 405-429. http://dx.doi.org/10.1016/0883-9026(91)90028-C

Davidsson, P., \& Honig, B. (2003). The role of social and human capital among nascent entrepreneurs. Journal of Business Venturing, 18(3), 301-331. http://dx.doi.org/10.1016/S0883-9026(02)00097-6 
Deakins, D., \& Freel, M. (1998). Entrepreneurial learning and the growth process in SMEs. The Learning Organization, 5(3), 144-155. http://dx.doi.org/10.1108/09696479810223428

Dillon, W. R., \& Goldstein, M. (1984). Multivariate analysis. New York: Wiley.

Douglas, E. J., \& Shepherd, D. A. (2002). Self-employment as a career choice: Attitudes, entrepreneurial intentions, and utility maximization. Entrepreneurship Theory and Practice, 26(3), 81-90.

Ellis, S., Mendel, R., \& Nir, M. (2006). Learning from successful and failed experience: The moderating role of kind of after-event review. Journal of Applied Psychology, 91(3), 669-680. http://dx.doi.org/10.1037/00219010.91.3.669

Fairlie, R. W., \& Meyer, B. D. (1996). Ethnic and racial self-employment differences and possible explanations. Journal of Human Resources, 31(4), 757-793. http://dx.doi.org/10.2307/146146

Gibb, A. A. (1997). Small firms' training and competitiveness. Building upon the small business as a learning organisation. International Small Business Journal, 15(3), 13-29. http://dx.doi.org/10.1177/0266242697 153001

Gilad, B., \& Levine, P. (1986). A behavioral model of entrepreneurial supply. Journal of Small Business Management, 24(4), 45-53.

Gimeno, J., Folta, T. B., Cooper, A. C., \& Woo, C. Y. (1997). Survival of the fittest? Entrepreneurial human capital and the persistence of underperforming firms. Administrative Science Quarterly, 42(4), 750-783. http://dx.doi.org/10.2307/2393656

Greene, P. (2000). Self-employment as an economic behavior: An analysis of self-employed women's human and social capital. National Journal of Sociology, 12(1), 1-55.

Guerrero, M., Rialp, J., \& Urbano, D. (2008). The impact of desirability and feasibility on entrepreneurial intentions: A structural equation model. International Entrepreneurship and Management Journal, 4(1), 35-50. http://dx.doi.org/10.1007/s11365-006-0032-x

Hannafey, F. T. (2003). Entrepreneurship and ethics: A literature review. Journal of Business Ethics, 46(2), 99-110. http://dx.doi.org/10.1023/A:1025054220365

Headd, B. (2003). Redefining business success: Distinguishing between closure and failure. Small Business Economics, 21(1), 51-61. http://dx.doi.org/10.1023/A:1024433630958

Henley, A. B., Shook, C. L., \& Peterson, M. (2006). The presence of equivalent models in strategic management research using structural equation modeling assessing and addressing the problem. Organizational Research Methods, 9(4), 516-535. http://dx.doi.org/10.1177/1094428106290195

Hu, L. T., \& Bentler, P. M. (1998). Fit indices in covariance structure modeling: Sensitivity to underparameterized model misspecification. Psychological methods, 3(4), 424. http://dx.doi.org/10.1037/ 1082-989X.3.4.424

Hughes, J. (2007). The ability-motivation-opportunity framework for behavior research in IS. Paper presented at the System Sciences, 2007. HICSS 2007., 40th Annual Hawaii International Conference on System Sciences.

Keeble, D., Bryson, J., \& Wood, P. (1992). The rise and role of small service firms in the United Kingdom. International Small Business Journal, 11(1), 11-22. http://dx.doi.org/10.1177/026624269201100101

Keister, L. A. (2000). Wealth in America: Trends in wealth inequality. New York: Cambridge University Press. http://dx.doi.org/10.1017/CBO9780511625503

Kim, P. H., Aldrich, H. E., \& Keister, L. A. (2003). If I were rich? The impact of financial and human capital on becoming a nascent entrepreneur. Paper presented at the Annual Meeting of the American Sociological Association, Atlanta.

Kim, P. H., Aldrich, H. E., \& Keister, L. A. (2006). Access (not) denied: The impact of financial, human, and cultural capital on entrepreneurial entryin the United States. Small Business Economics, 27(1), 5-22. http://dx.doi.org/10.1007/s11187-006-0007-x

Klepper, S. (2002). The capabilities of new firms and the evolution of the US automobile industry. Industrial and Corporate Change, 11(4), 645-666. http://dx.doi.org/10.1093/icc/11.4.645

Knott, A. M., \& Posen, H. E. (2005). Is failure good? Strategic Management Journal, 26(7), 617-641. http://dx. doi.org/10.1002/smj. 470 
Krueger Jr, N. F., Reilly, M. D., \& Carsrud, A. L. (2000). Competing models of entrepreneurial intentions. Journal of Business Venturing, 15(5), 411-432. http://dx.doi.org/10.1016/S0883-9026(98)00033-0

Krueger, N. F. (1993). The impact of prior entrepreneurial exposure on perceptions of new venture feasibility and desirability. Entrepreneurship Theory and Practice, 18(1), 5-21.

Lazear, E. P. (2004). Balanced skills and entrepreneurship. The American Economic Review, 94(2), 208-211. http://dx.doi.org/10.1257/0002828041301425

Lin, H. C., \& Shih, C. T. (2008). How Executive SHRM System Links to Firm Performance: The Perspectives of Upper Echelon and Competitive Dynamics. Journal of Management, 34(5), 853-881. http://dx.doi.org/10. 1177/0149206308318612

MacInnis, D. J., Moorman, C., \& Jaworski, B. J. (1991). Enhancing and measuring consumers' motivation, opportunity, and ability to process brand information from ads. The Journal of Marketing, 55(4), 32-53. http://dx.doi.org/10.2307/1251955

Mathieu, J. E., Tannenbaum, S. I., \& Salas, E. (1992). Influences of individual and situational characteristics on measures of training effectiveness. Academy of Management Journal, 35(4), 828-847. http://dx.doi.org/10. $2307 / 256317$

McGrath, R. G. (1999). Falling forward: Real options reasoning and entrepreneurial failure. Academy of Management Review, 24(1), 13-30. http://dx.doi.org/10.2307/259034

Mezirow, J. (1991). Transformative dimensions of adult learning. San Francisco: Jossey-Bass.

Minniti, M., \& Bygrave, W. (2001). A dynamic model of entrepreneurial learning. Entrepreneurship Theory and Practice, 25(3), 5-16.

Orhan, M., \& Scott, D. (2001). Why women enter into entrepreneurship: An explanatory model. Women in Management Review, 16(5), 232-247. http://dx.doi.org/10.1108/09649420110395719

Pedhazur, E. J., \& Schmelkin, L. P. (1991). Measurement, design, and analysis: An integrated approach. New Jersey: Lawrence Erlbaum Asociates, Inc.

Peng, M. W., \& Barney, J. B. (2007). Bankruptcy law and entrepreneurship development: A real options perspective. Academy of Management Review, 32(1), 257-272. http://dx.doi.org/10.5465/AMR.2007. 23464070

Peters, L. H., \& O'Connor, E. J. (1980). Situational constraints and work outcomes: The influences of a frequently overlooked construct. Academy of Management Review, 5(3), 391-397.

Phillips, D. J. (2002). A genealogical approach to organizational life chances: The parent-progeny transfer among Silicon Valley law firms, 1946-1996. Administrative Science Quarterly, 47(3), 474-506. http://dx.doi.org/10. $2307 / 3094848$

Politis, D. (2005). The process of entrepreneurial learning: A conceptual framework. Entrepreneurship Theory and Practice, 29(4), 399-424. http://dx.doi.org/10.1111/j.1540-6520.2005.00091.x

Rae, D., \& Carswell, M. (2000). Using a life-story approach in researching entrepreneurial learning: The development of a conceptual model and its implications in the design of learning experiences. Education and Training, 42(4/5), 220-228. http://dx.doi.org/10.1108/00400910010373660

Robinson, P. B., \& Sexton, E. A. (1994). The effect of education and experience on self-employment success. Journal of Business Venturing, 9(2), 141-156. http://dx.doi.org/10.1016/0883-9026(94)90006-X

Rosenbusch, N., Brinckmann, J., \& Bausch, A. (2011). Is innovation always beneficial? A meta-analysis of the relationship between innovation and performance in SMEs. Journal of Business Venturing, 26(4), 441-457. http://dx.doi.org/10.1016/j.jbusvent.2009.12.002

Rothschild, M. L. (1999). Carrots, sticks, and promises: A conceptual framework for the management of public health and social issue behaviors. The Journal of Marketing, 63(4), 24-37. http://dx.doi.org/10.2307/1251 972

Segal, G., Borgia, D., \& Schoenfeld, J. (2005). The motivation to become an entrepreneur. International Journal of Entrepreneurial Behaviour \& Research, 11(1), 42-57. http://dx.doi.org/10.1108/13552550510580834

Shah, R., \& Goldstein, S. M. (2006). Use of structural equation modeling in operations management research: Looking back and forward. Journal of Operations Management, 24(2), 148-169. http://dx.doi.org/10.1016/j. jom.2005.05.001 
Shane, S. (2000). Prior knowledge and the discovery of entrepreneurial opportunities. Organization Science, 11(4), 448-469. http://dx.doi.org/10.1287/orsc.11.4.448.14602

Shapero, A., \& Sokol, L. (1982). The social dimensions of entrepreneurship. New Jersey: Prentice Hall.

Shepherd, D. A. (2003). Learning from business failure: Propositions of grief recovery for the self-employed. Academy of Management Review, 28(2), 318-328.

Shepherd, D. A., Patzelt, H., \& Wolfe, M. (2011). Moving forward from project failure: Negative emotions, affective commitment, and learning from the experience. Academy of Management Journal, 54(6), 1229-1259. http://dx.doi.org/10.5465/amj.2010.0102

Siemsen, E., Roth, A. V., \& Balasubramanian, S. (2008). How motivation, opportunity, and ability drive knowledge sharing: The constraining-factor model. Journal of Operations Management, 26(3), 426-445. http://dx.doi.org/10.1016/j.jom.2007.09.001

Stevenson, H. H., \& Jarillo, J. C. (1990). A paradigm of entrepreneurship: Entrepreneurial management. Strategic Management Journal, 11(5), 17-27.

Subramaniam, M., \& Youndt, M. A. (2005). The influence of intellectual capital on the types of innovative capabilities. Academy of Management Journal, 48(3), 450-463. http://dx.doi.org/10.5465/AMJ.2005. 17407911

Van Praag, C. M., \& Cramer, J. S. (2001). The roots of entrepreneurship and labour demand: Individual ability and low risk aversion. Economica, 68(269), 45-62. http://dx.doi.org/10.1111/1468-0335.00232

Venkataraman, S. (2002). The distinctive domain of entrepreneurship research. Advances in Entrepreneurship, Firm Emergence and Growth, 3(1), 119-138.

Warren, E., \& Westbrook, J. L. (1999). Financial characteristics of businesses in bankruptcy. American Bankruptcy Law Journal, 73(1), 499-521.

White, M. J. (1989). The corporate bankruptcy decision. The Journal of Economic Perspectives, 3(2), 129-151. http://dx.doi.org/10.1257/jep.3.2.129

Wu, Y., Balasubramanian, S., \& Mahajan, V. (2004). When is a preannounced new product likely to be delayed? Journal of Marketing, 68(2), 101-113. http://dx.doi.org/10.1509/jmkg.68.2.101.27792

Youndt, M. A., Subramaniam, M., \& Snell, S. A. (2004). Intellectual Capital Profiles: An Examination of Investments and Returns. Journal of Management Studies, 41(2), 335-361. http://dx.doi.org/10.1111/j.1467 $-6486.2004 .00435 . x$

\section{Appendix}

Appendix A1. Entrepreneurial failure learning. The questions relate to your ability to learn from your failure

\begin{tabular}{lllllllll}
\hline Entrepreneurial Failure Learning & \multicolumn{3}{c}{$\begin{array}{l}\text { Strongly } \\
\text { Disagree Agree }\end{array}$} \\
\hline 1 & After failure, I can understand deeply about my strong point & 1 & 2 & 3 & 4 & 5 & 6 & 7 \\
2 & I also can understand more about my weakness point & 1 & 2 & 3 & 4 & 5 & 6 & 7 \\
3 & $\begin{array}{l}\text { After business failed, I can aware which is really important in my life and my } \\
\text { family }\end{array}$ & 1 & 2 & 3 & 4 & 5 & 6 & 7 \\
4 & I can set a clear goal in the future & 1 & 2 & 3 & 4 & 5 & 6 & 7 \\
5 & I have learned a useful lesson about the customer's need as well as the market & 1 & 2 & 3 & 4 & 5 & 6 & 7 \\
6 & $\begin{array}{l}\text { I can build a strong relationship with my partners after learning the lesson from } \\
\text { failure }\end{array}$ & 1 & 2 & 3 & 4 & 5 & 6 & 7 \\
7 & I am more willing to help others deal with their failure & 1 & 2 & 3 & 4 & 5 & 6 & 7 \\
\hline
\end{tabular}


Appendix A2. Entrepreneurial resources. The questions relate to what do you have for your entrepreneurs

\begin{tabular}{lllllllll}
\hline \multirow{2}{*}{ Entrepreneurial Resources } & \multicolumn{3}{l}{$\begin{array}{l}\text { Strongly } \\
\text { Disagree Agree }\end{array}$} \\
\hline 1 & I am highly skilled & 1 & 2 & 3 & 4 & 5 & 6 & 7 \\
2 & I am widely considered the best in our industry & 1 & 2 & 3 & 4 & 5 & 6 & 7 \\
3 & I am creative and bright & 1 & 2 & 3 & 4 & 5 & 6 & 7 \\
4 & I am experts in their particular jobs and functions & 1 & 2 & 3 & 4 & 5 & 6 & 7 \\
5 & I develop new ideas and knowledge & 1 & 2 & 3 & 4 & 5 & 6 & 7 \\
\hline
\end{tabular}

Appendix A3. Entrepreneurial restart intention. The questions relate to your intention to restart business

\begin{tabular}{lllllllll}
\hline \multirow{2}{*}{\begin{tabular}{l} 
Entrepreneurial Restart Intention \\
\cline { 2 - 7 }
\end{tabular}} & \multicolumn{3}{l}{$\begin{array}{l}\text { Strongly } \\
\text { Disagree Agree }\end{array}$} \\
\hline 1 & I would love to be an entrepreneur & 1 & 2 & 3 & 4 & 5 & 6 & 7 \\
2 & To be an entrepreneur is my honor & 1 & 2 & 3 & 4 & 5 & 6 & 7 \\
3 & I am considering re-starting my own business some day in the future & 1 & 2 & 3 & 4 & 5 & 6 & 7 \\
4 & To be an entrepreneur is very hard & 1 & 2 & 3 & 4 & 5 & 6 & 7 \\
5 & I am certain in this restart firm & 1 & 2 & 3 & 4 & 5 & 6 & 7 \\
6 & I am sure about myself to re-stat business & 1 & 2 & 3 & 4 & 5 & 6 & 7 \\
7 & I can recovery my losing reputation when I restart my own business & 1 & 2 & 3 & 4 & 5 & 6 & 7 \\
\hline
\end{tabular}

\section{Other information}

1. Gender: $\square$ Male $\square$ Female

2. Age: $\square<21 \square<21-30 \square<31-40 \square<41-50 \square<51-60 \square>60$

3. Number of venture:

4. Education: $\square$ Primary school $\square$ High school $\square$ Bachelor $\square$ Master and above $\square$ Others

5. Firm age (years) before failure:

6. Firm industry before failure (what kind of products and service provided before failure):

7. Firm location (which country is your company located). Please specify:

8. Total number of employees in your company:

9. Total number of entrepreneurial team member (including you):

10. Any comments towards Restart Intention.

\section{Copyrights}

Copyright for this article is retained by the author(s), with first publication rights granted to the journal.

This is an open-access article distributed under the terms and conditions of the Creative Commons Attribution license (http://creativecommons.org/licenses/by/3.0/). 